\title{
The 'miraculous' föhn in Bavaria of January 1704
}

\section{Klaus P. Hoinka ${ }^{1}$, Arnold Tafferner ${ }^{1}$ and Leo Weber ${ }^{2}$}

\author{
${ }^{1}$ Institut für Physik der Atmosphäre, DLR, \\ Wessling, Germany \\ 2 Philosophisch-Theologische \\ Hochschule der Salesianer Don Boscos, \\ Benediktbeuern, Germany
}

Systematic weather observations were started in earnest in the nineteenth century when the first national weather services were established. Before the establishment of these institutions, there was a significant interest in observing the weather by individuals such as priests, writers and artists. These observations were sometimes performed unsystematically and yet there are known historical weather events which are reasonably well documented by location, date, intensity and even daily evolution. An example is the southerly föhn, one of the dominant weather phenomena in Bavaria, southern Germany. One particular event occurred on 28 January 1704, documented by Carolus Meichelbeck (1669-1734), a monk at the Monastery Benediktbeuern. He reported that this föhn rapidly melted the frozen marshes surrounding the monastery and saved the monastery from being plundered by Tyrolean troops during the Spanish Succession War. This melting was so impressive that the chronicler praised this saving of the monastery as a divine marvel, the so-called 'Anastasia' or 'Lake Kochel' miracle. In the following we will determine if realistic meteorological conditions during this föhn event would allow the reported strong and rapid melting of the water in the marshes.

\section{Topographical background}

The main characteristic of a strong föhn wind is its gustiness associated with a significant increase in the near-surface temperature. Meichelbeck (1710) reported that the föhn of 28 January 1704 dramatically melted the frozen swamps very close to the Alpine baseline around $60 \mathrm{~km}$ south of Munich (Figure 1). The valleys of the rivers Loisach and Isar open towards the Bavarian

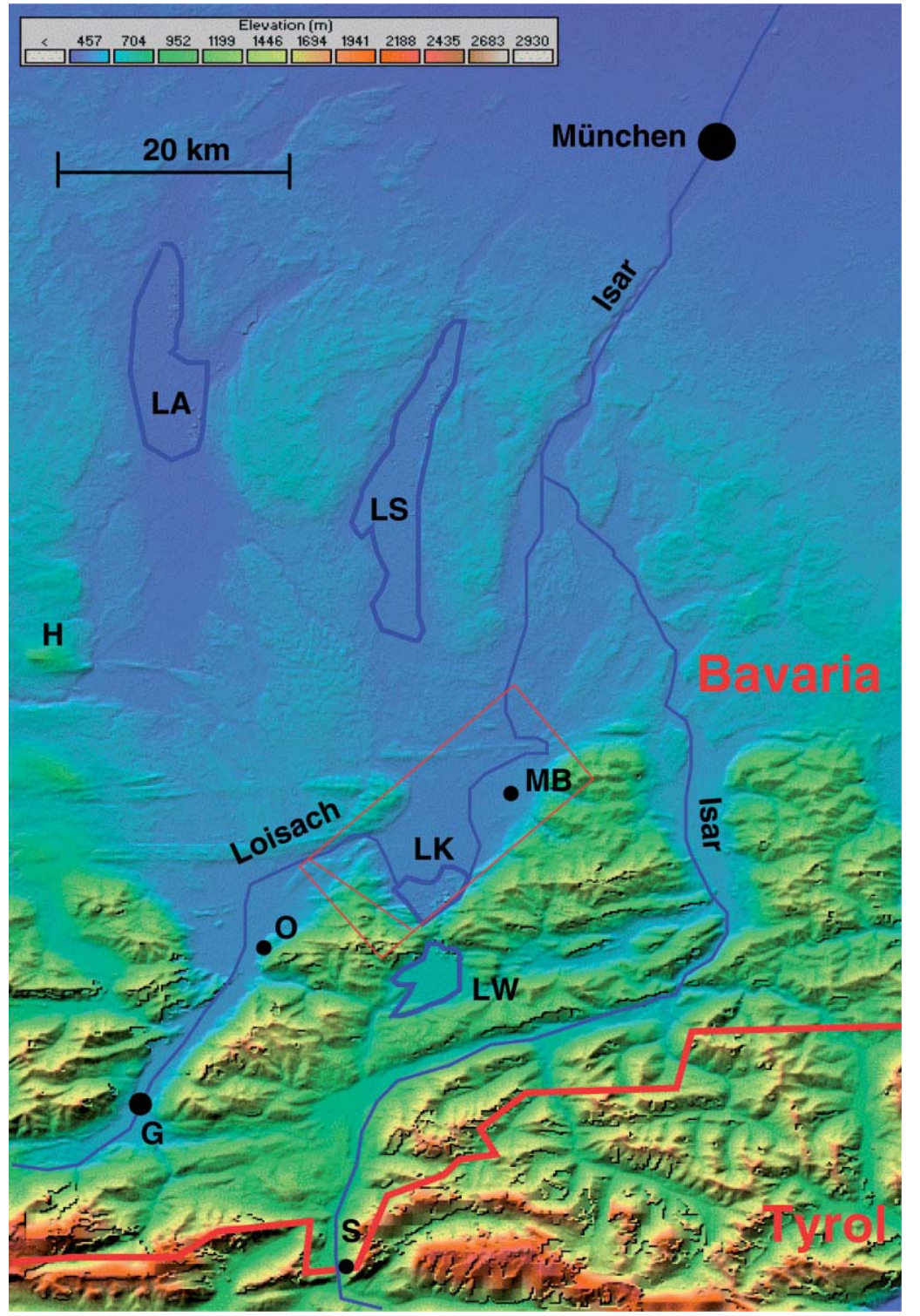

Figure 1. Map of southern Bavaria and parts of Tyrol showing the Isar and Loisach rivers and the following locations: Garmisch-Partenkirchen (G), Ohlstadt (O), Hohenpeissenberg (H), Scharnitz (S), Monastery of Benediktbeuern (MB), Lake Ammer (LA), Lake Starnberg (LS), Lake Kochel (LK), Lake Walchen $(L W)$. The rectangle delimited by the red line indicates the area shown in Figure 3. The scale is 1:100.000. (Elevation data, ๑ U.S. Geological Survey.)

plains. The Monastery of Benediktbeuern (MB in Figure 1) (Box 1) is located close to the Alpine baseline. Between Lake Kochel and Lake Walchen (LK and LW in Figure 1) south of the monastery there is a mountain gap, with nearby mountain summits reaching more than $1400 \mathrm{~m}$. Figure 2 shows a summertime view from the north toward the monastery with the gap and surrounding mountains. It is well known that mountain gaps enhance and intensify strong downslope windstorms, for example, the chinook of Colorado (Brinkmann, 1974). A small hill (H) indicates the mountain observatory 


\section{Box 1. Monastery Benediktbeuern.}

The monastery, founded in the early eighth century, is one of the most important monasteries located at the northern Alpine rim. The most famous monk of this monastery, Carolus Meichelbeck (1669-1734), is known as the father of the Bavarian science of history. He worked in the monastery's library which contained about 30000 books. Among them was the original document of the well-known Carmina Burana, a collection of lyrics, songs and texts of the eleventh, twelfth and thirteenth centuries originating from Carinthia. Besides St Benedict, St Anastasia is also the monastery's Saint. The monastery's Abbot felt obliged to build a new chapel (1750-1753) in honour of the Saint for her help in saving the monastery from being plundered during the Spanish Succession War. The chapel is one of the most perfect examples of Rococo-style architecture in Upper Bavaria. Today it is open to the public. For an extended description of the monastery's history see Weber (1991).

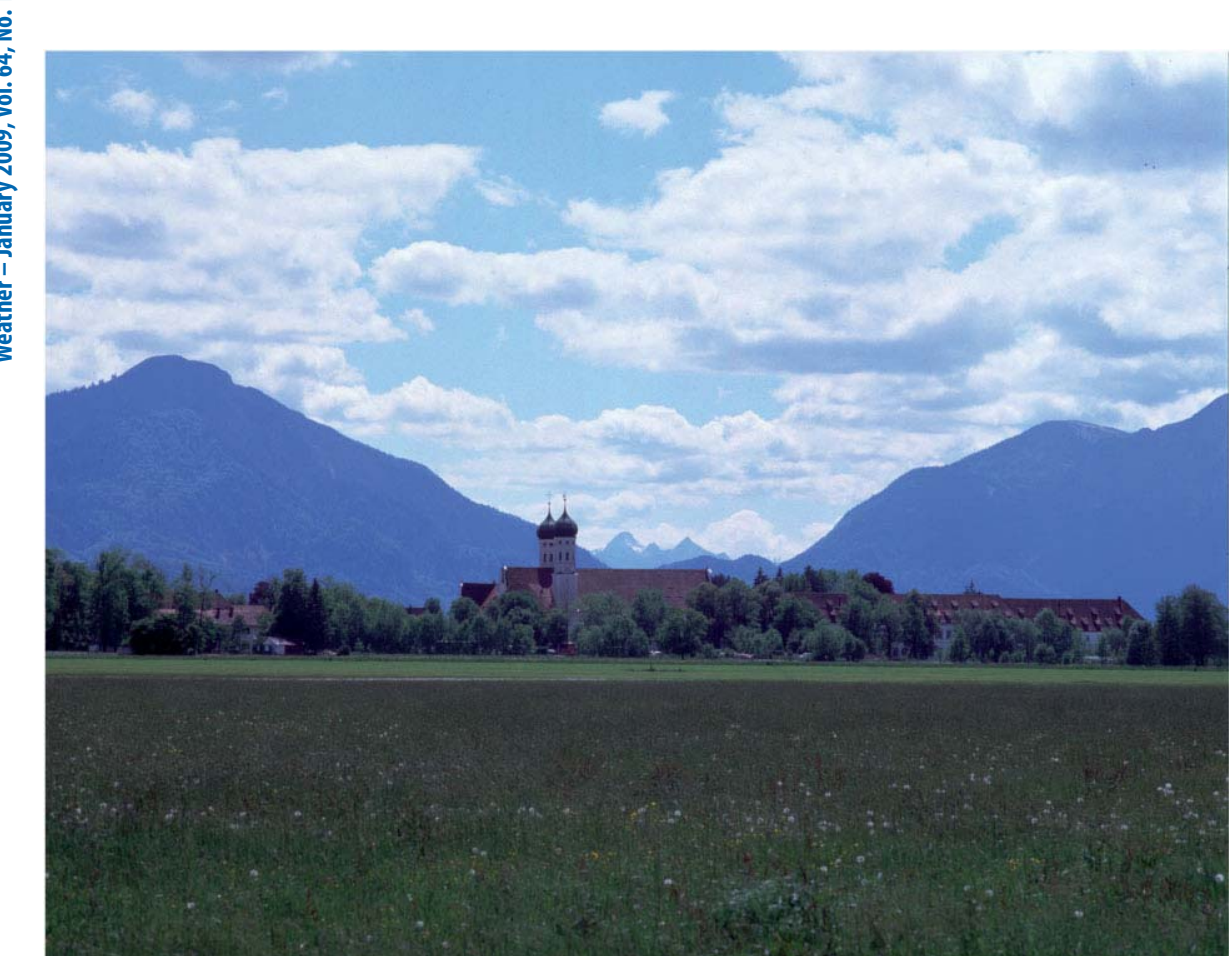

Figure 2. Summertime view from the north towards the monastery of Benediktbeuern in front of the mountain gap between Lake Walchen and Lake Kochel. (๑ Arnold Tafferner.)
Hohenpeissenberg (989 m), famous for its worldwide longest series of meteorological observations starting around 1789.

For centuries the monastery was surrounded by swamps with imbedded small swamp ponds and hamlets. These wet areas hampered approaching invaders providing a natural defence. Figure 3 shows the topographical situation at the beginning of the nineteenth century (Schleich, 1807). The German words Moos and Filtz, appearing on the map, stand for moss and swamp, respectively. The monastery is surrounded by mountains (east), and extended swamp areas (west) to both sides of the River Loisach. To the south there was a small road across the pass between Lake Kochel and Lake Walchen from which Meichelbeck (1710) said that it was so narrow that it was impossible for two vehicles to pass side by side. At the end of the nineteenth century the water level of the Lake Kochel was lowered by more than $2 \mathrm{~m}$. Today the entire swamp area around the monastery is covered by a network of small drainage canals, almost all swamp ponds have disappeared and the former swamp area consists of solid terrain.

\section{Historical background}

From the beginning of the Spanish Succession War (1701-1714), Bavaria and Tyrol served as major staging areas for imperial forces. In October 1702, Max Emanuel, elector of Bavaria, declared the separation of Tyrol from Bavaria (originating from 1363) invalid and announced his intention of regaining it for Bavaria. In early 1703, Bavarian troops entered Tyrol and took Innsbruck. Faced by a massive uprising of Tyrolean peasantry in defending their homeland, Max Emanuel and his army of regulars had suffered a humiliating defeat by a poorly trained but highly motivated peasantry within eight

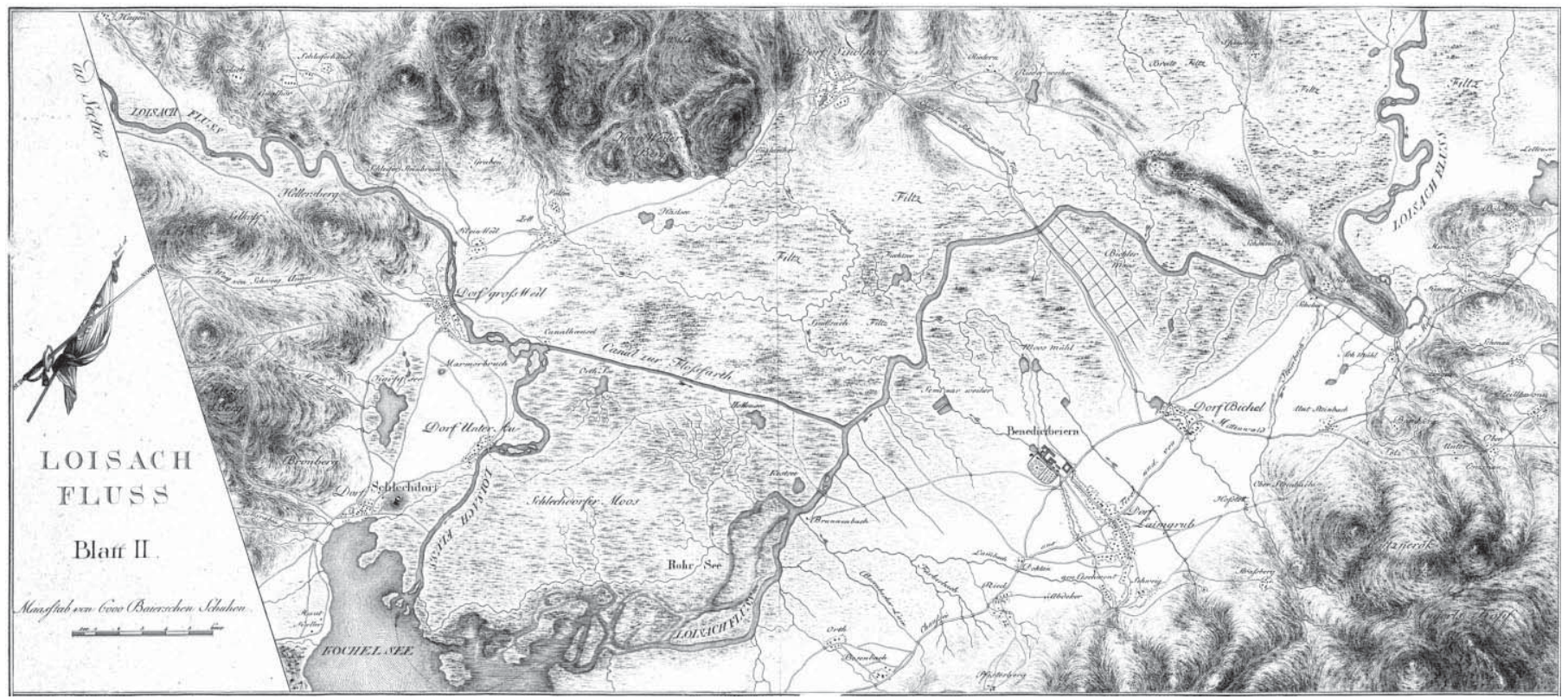

Figure 3. Map of Loisach area (Schleich, 1807). The distance across the map from top to bottom is $10 \mathrm{~km}$. (๑ Bayerische Staatsbibliothek, München.) 
weeks in the summer 1703. After the inglorious end of Max Emanuel's Tyrolean adventure in the autumn, the Tyroleans considered taking their revenge against Bavaria.

The Tyroleans demanded reparation from the monastery's Prior, among others, combined with the threat to conquer and to burn down the monastery. He refused to pay because he felt himself innocent of the politics of Max Emanuel. A possibility of a revenge campaign occurred in January 1704 when lakes and rivers were heavily frozen in the northern Alpine area due to very low winter temperatures. The Tyrolean troops, peasantry and Tyrolean mountain riflemen (Gebirgs-Schützen'), which were stationed at the border fortress of Scharnitz ( $S$ in Figure 1) saw a very promising chance of attacking Bavaria and plundering the monastery.

The topography offers three options for a military approach from Tyrol towards the monastery (Figure 1): First, invading Bavaria along the Isar Valley; secondly moving through the mountain gap between Lake Walchen and Lake Kochel; and thirdly following the Loisach Valley and passing the village of Großweil (Figure 3). The first option provided too long an approach. The road across the gap, built in 1492, contained steep gradients of up to $25 \%$ which could be crossed only with the help of an extra team of horses and this pass could be easily defended. Therefore, the easiest way to get to the monastery was the route along the Loisach Valley. The only disadvantage was the swamp area between Schlehdorf and Benediktbeuern (Figure 3) because at this time a direct road connection did not exist. But January of 1704 was a very cold month with sufficiently frozen surfaces. At the end of the seventeenth century, in the period known as the Little Ice Age, the strongest temperature depression of about -2 deg $C$ below the early twentieth-century average (1901-1960) occurred between 1680 and 1700 (Pfister, 1992). After this period, the temperatures remained below normal; for example, in Switzerland the mean temperature of January 1704 was about 1 deg C lower than normal.

\section{January 1704}

In the early morning of 28 January 1704 , 2000 Tyrolean horsemen and soldiers started from Scharnitz (S, Figure 1) (Meichelbeck, 1710). They moved to Garmisch and then along the Loisach River Valley, passing Ohlstadt towards Großweil close to Lake Kochel. Following a secret plan, they used secondary roads in order keep their approach secret. However, passing through small villages, the armada was discovered by residents and later on reported to the monastery by refugees. After reaching the village of Großweil (Figure 3) the Tyroleans

\footnotetext{
${ }^{1}$ In Bavaria and Tyrol a non-military troop of
} voluntary riflemen. planned to move along a dead-straight line over the frozen swamps and the River Loisach towards the monastery. This advance line coincides approximately with the later (1712) constructed canal (Figure 3; Canal zur Floßfahrth). It was hoped to arrive at the monastery in the evening.

Meichelbeck (1710) pointed out that Lake Kochel was so strongly frozen that heavy load cars and 1000 men could have moved comfortably towards Benediktbeuern. When first notices of the troop's advance arrived, the monastery's authorities did not believe it. But finally these notices were acknowledged when the number of refugees increased dramatically and when it was reported that the troops had reached Ohlstadt. Because it was too late to organize an effective defence of the monastery, its salvation was entrusted to God. The next day, 29 January, was the festival day in honour of St Anastasia. Traditionally a liturgical vespers for Anastasia is celebrated on the preceding evening. Besides the worry of the danger related to the approach of Tyrolean troops, the monks were anxious about not being able to fulfil this duty. At noon they started to pray to Anastasia for her help in this dangerous situation.

Meichelbeck (1710) reports that at $1400 \mathrm{~h}$ when the Tyrolean troops were about one hour away from the frozen swamps, a very warm wind appeared. Three to four hours later, the frozen swamps turned from white to black indicating that they were impassable for horses. As soon as the troops had reached the swamp areas they recognized that it was impossible for them to cross these melting surfaces because horses and men broke into the unsound ice surface. Meichelbeck mentioned also that the wind was persistently warm.

\section{Föhn and ice melting}

The effect of the sudden föhn-related warming and the resulting melting of the frozen swamp must have been so impressive that for Meichelbeck (1710) the only explanation was that it was a miracle. Here a rough estimate is made to evaluate the melting effect, taking into account temporal limits and intensity reported by Meichelbeck (1710).

At first, the minimum ice-layer thickness is determined which is necessary for bearing the mean weight of a horse with horseman of about $700 \mathrm{~kg}$. The minimum ice-layer thickness with bearing capacity can be approximated empirically (Kerr, 1996):

$$
\mathrm{h}_{\min }=\left(P \cdot n \cdot A^{-1}\right)^{0.5}
$$

with the constant $A=0.01$ and the factor $n$ which describes the ice quality ranging between 1.0 (solid winter ice) and 4.8 (springtime ice). With the bearing capacity $P$ in tons, $\mathrm{h}_{\min }$ is given in $\mathrm{cm}$. For an average weight horseman $h_{\min }$ ranges between 10 and $20 \mathrm{~cm}$ above lakes.
The core of the meltwater production model consists of an energy balance approach (Escher-Vetter, 2000). This model delivers the available melt energy as the sum of shortwave and longwave radiation balance, as well as sensible and latent heat fluxes. Under normal conditions, most of the energy used for melting is supplied by radiation, followed by the sensible heat flux and only a minor fraction is derived from latent heat. Turbulent exchange of heat can be quite significant, especially in winter when the sun is low. For reasons of simplicity, only the sensible heat flux is evaluated without taking into account sublimation of ice or evaporation of melted water. The sensible heat flux $S$ is calculated by a simple bulk approach $\mathrm{S}=-\alpha \cdot\left(T_{s}-T_{\alpha}\right)$, where $\left(T_{s}-T_{\alpha}\right)$ is the surface/air temperature difference. The heat transfer coefficient $\alpha$ is approximated by $\alpha=5.7 \cdot \sqrt{v}$. With the horizontal wind $v$ in $\mathrm{m} \mathrm{s}^{-1}, \alpha$ results to $\mathrm{Wm}^{-2} \mathrm{~K}^{-1}$.

The water-equivalent melt rate $M_{w}$ indicates the total change in time of the ice mass, calculated by:

$$
M_{w}=\mathrm{S} \cdot\left(\rho_{\mathrm{w}} \cdot r\right)^{-1}
$$

with density of water $\rho_{w}$, heat of fusion $r$ $\left(3.35 \times 10^{5} \mathrm{Jkg}^{-1}\right)$ and $\mathrm{S}$ in $\mathrm{Wm}^{-2}, \mathrm{M}_{\mathrm{w}}$ is given in $\mathrm{m} \mathrm{s}^{-1}$. The $\mathrm{M}_{w}$ is equivalent to $0.9 \cdot \mathrm{M}_{\mathrm{e}^{\prime}}$, where the latter represents the ice-equivalent. Figure 4 shows snow melting as a function of temperature difference for different surface wind speeds.

According to Meichelbeck (1710), the föhn started at noon and about three to four hours later the solidity of the frozen swamp surface was too weak to bear a horseman. The onset of föhn is associated with a sudden temperature rise. Brinkmann (1974) pointed out that maximum increases are on average $10 \mathrm{deg} C$ for the European Alps and $15 \mathrm{deg} C$ for the Rocky Mountains, although extreme cases exceeding 20 deg $C$ have been reported. Speeds of gust of $45 \mathrm{~m} \mathrm{~s}^{-1}$ are not uncommon in these windstorms (Julian and

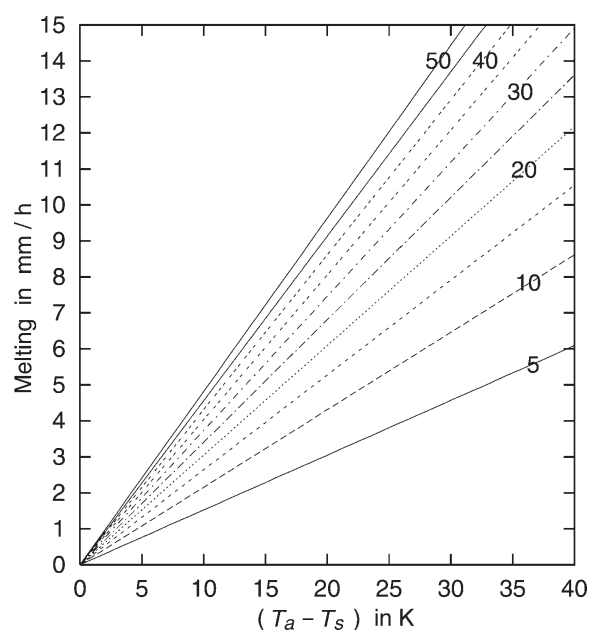

Figure 4. Snow melting as a function of difference between soil and air temperature $\left(T_{a}-T_{s}\right)$ for different surface wind speeds in $\mathrm{m} \mathrm{s}^{-1}$. 
Julian, 1969). Assuming a wind of $35 \mathrm{~m} \mathrm{~s}^{-}$ 1 and a temperature difference $\left(T_{a}-T_{s}\right)$ of $20 \operatorname{deg} C$ we arrive at an ice melt rate of about $8.5 \mathrm{~mm} \mathrm{~h}^{-1}$. Thus a solid lake ice-layer would be reduced by $2.5 \mathrm{~cm}$ within 3 hours.

One has to keep in mind that the solidity of lake ice and of a frozen swamp surface are quite different because the latter consists of a frozen mixture of grass, small plants, soil and water. This mixture needs less energy for melting the iced parts of the soil before losing its bearing capacity. A heat flux of a certain magnitude will melt a much deeper layer of frozen swamp than of lake ice. Assuming a melting of swamp layer to be twice as effective compared to lake ice, we arrive at an estimate of about $5 \mathrm{~cm}$ within 3 hours. The evaluated thickness reduction is not very dramatic but sufficient to change a frozen surface from bearing to non-bearing capacity.

Meichelbeck might have dramatized the event's intensity by shortening the impact period in order to increase the 'miracle's' significance. Increasing the period up to 6 hours between the outbreak of the föhn and the recognition of the non-bearing capacity, the abovementioned values increase to $10 \mathrm{~cm}$ for a frozen swamp. This estimate, being of the same order as the minimum bearing capacity, suggests that the transition from bearing to non-bearing capacity of the frozen swamp surface is very probable within this short period of time. Because the necessary meteorological conditions are not beyond its common range, no compelling evidence is indicated that a 'miracle' occurred. It suggests that the föhn of 28 January 1704 was an extraordinary event provided that Meichelbeck has correctly documented the times. Nevertheless, we must admit that a natural explanation did not always preclude a preternatural one.

\section{Artistic depiction of the föhn event}

From a meteorological standpoint it is interesting to look at an artistic depiction of this exceptional föhn. Figure 5 shows a painting by Lucas Zais describing the miracle of the föhn of 28 January 1704. In an aerial view from the north it shows the monastery and the mountain gap between Lake Walchen and Lake Kochel, to some extent similar to the photograph of Figure 2. A dark cloud layer covers the Alpine foreland, including the monastery. Above the mountain gap a bright föhn sky sketches the gap's contour clearly, illuminates mountain peaks located behind the gap, and sheds some light on the monastery.

This is a typical view from the north towards the Alps in föhn conditions. The effect depends on the strength of the föhn and on the three-dimensional atmospheric conditions such as humidity, wind and tem-

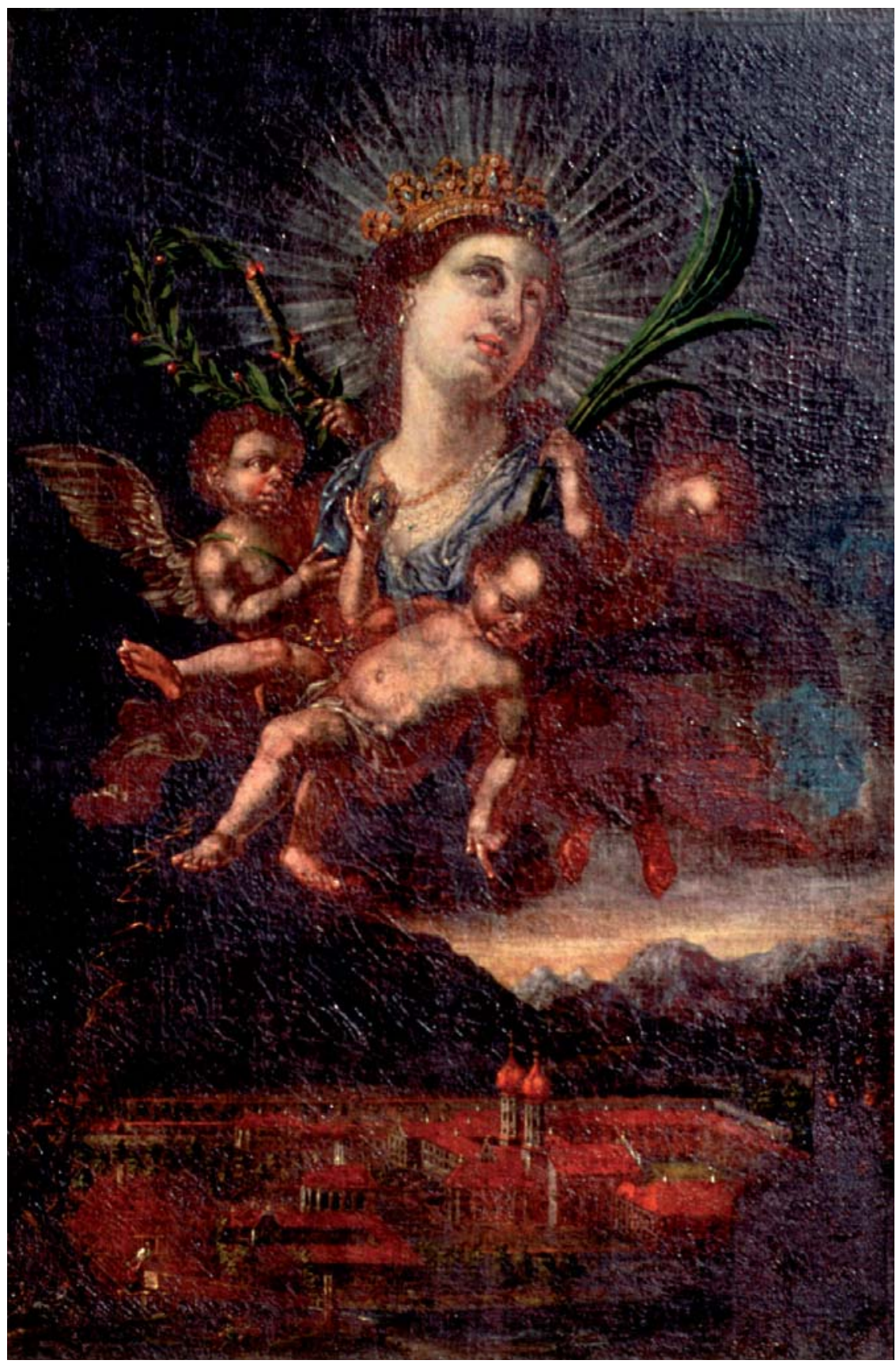

Figure 5. The Anastasia Miracle painted by Lucas Zais around 1720. The image size is about $1.3 \times 0.9 \mathrm{~m}$. (๑ Monastery of Benediktbeuern.)

limited as in the painting or of larger extent encompassing the entire northern Alps. An example is given in Figure 6 where the view from Munich is shown during the strong föhn event of 8 November 1982, the socalled 'föhn of the century' (Hoinka, 1985). The photo shows clearly the cloud gap above the Alpine barrier with a weak indication of a föhn wall (i.e., the nearly vertical leeward edge of the orographic cloud that occurs over the windward slopes and summits of high ground). Lenticular clouds above the Alpine foreland indicate lee-side mountain waves.

In the painting shown in Figure 5, St Anastasia hovers above the monastery surrounded by putto-type angels. To the left of her head appears a burning branch changing into a laurel wreath. This describes symbolically that God took heat from the fire which burned the Saint, providing this heat to Anastasia in form of the warm föhn air. This allowed Anastasia to save the monastery in the name of God and to be victorious over the Tyroleans. The state and quality of the painting does not permit the clear identification of more detail. However, Figure 7 shows a copper engraving (by Lucas Zais) exhibiting exactly the same pictorial representation. Obviously, the föhn effect of brightening the sky above the Alps is weaker due to this being a copper engraving.

Figure 8 shows an enlargement of part of Figure 7. Embedded into the mercy's beam is the Latin phrase non timebit domui suae (she is not worrying about her house) (Bible: Proverbs 31:21) indicating the protecting effect of Anastasia's plea. The sudden melting of the frozen swamp due to 

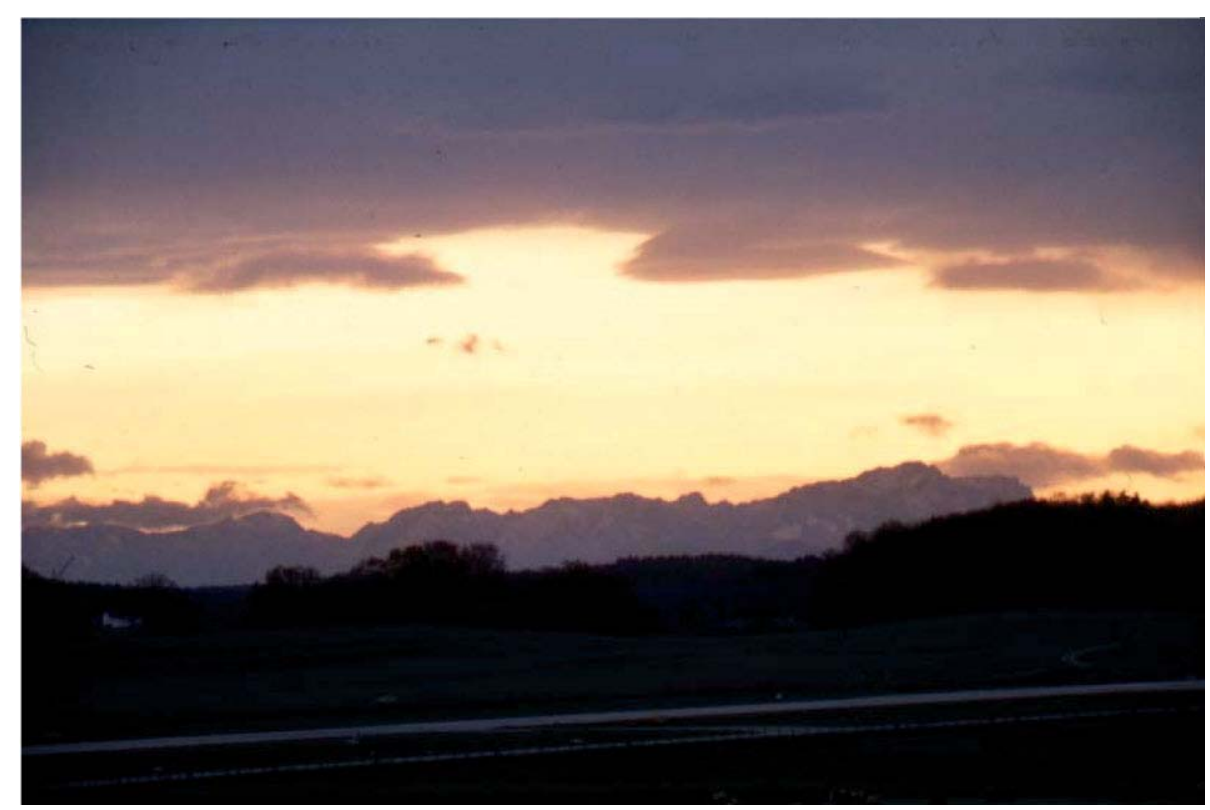

Figure 6. View towards the Alps from Munich during the föhn of 8 November 1982.

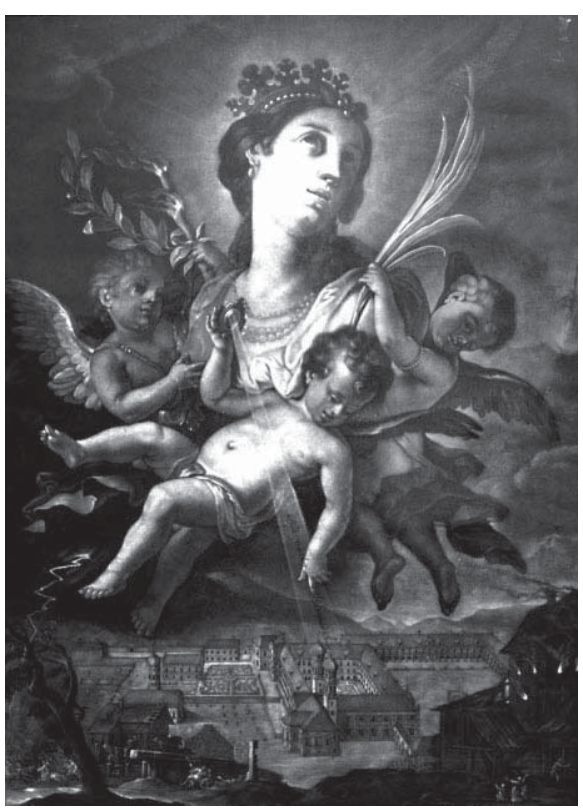

Figure 7. Copper engraving of the Anastasia Miracle engraved by Lucas Zais around 1720. (๑ Monastery of Benediktbeuern.)

föhn must have been so impressive that, following Meichelbeck's report (1710), the Tyrolean troops had been terrified of this marvel, a portent or sign that God and St Anastasia were on the monastery's side. On the left side a zigzagging flash and even rain can be seen pointing down to the fleeing Tyrolean horsemen, symbolically indicating God's punishment. On the right- and left-hand side houses burned by Tyrolean troops are shown after being plundered in various villages along their escape route. It is interesting to note that the smoke leaves the houses towards the engraving's left side. In relation to the mountain's aerial view, this indicates an easterly flow. However, the southerly föhn blows away from the mountains towards the observer. This suggests that, here, realistic details and solitary pictures are arranged in an unrealistic manner.

\section{Concluding remarks}

In mountainous regions, strong downslope winds have a considerable societal impact.

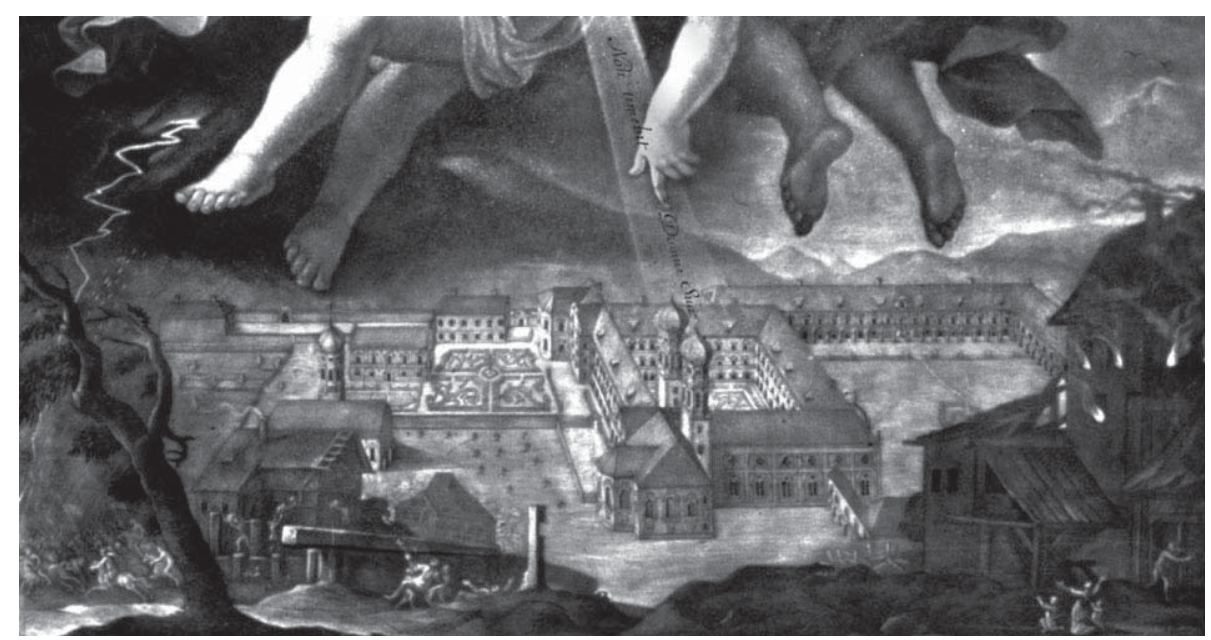

Figure 8. Enlargement of part of Figure 7 (see text for discussion).
For example, three severe Chinook storms cited by Brinkmann (1974) caused property damage estimated at up to US\$5 million, injured fifty people and killed two. Strong gusts of Chinooks have overturned mobile homes, trucks and aircraft and unroofed houses seriously enough to impede traffic (Julian and Julian, 1969). Similar effects are reported for strong Alpine föhn cases. An exceptional föhn occurred in 1846 when strong winds and high temperatures initiated a conflagration in Schlehdorf (Figure 3) burning down the entire village. A weak societal impact is also that some people suffer from headaches during föhn in Bavaria. But a very different impact becomes evident with the historical föhn of 1704 which prevented the plundering of the monastery at Benediktbeuern.

European Catholic countries show a wealth of wonders throughout the centuries, although meteorological 'miracles', such as the Anastasia one, are rare. However, another curious Bavarian example is the so-called 'fog-miracle' where late medieval Maria's plea and the prayers of Bishop Lantpert prevented the cathedral of Freising (north of Munich) from being plundered by invading Hungarian troops in the tenth century. The legend tells that the cathedral standing on top of a hill was surrounded by a dense fog and the troops missed it due to the poor visibility.

Until the end of the eighteenth century, too little was known of nature to locate the boundary between natural and supernatural causes. The invention of the barometer and thermometer marks the dawn of the study of atmospheric physics. The birth of scientific meteorology came with the publication of Halley's paper on the Trade Winds (1688), the formulation of Hooke's law (1703) and of Gay-Lussac's law (1702).

This new science changed the importance of wonders. If comets no longer terrified, if strange facts no longer fascinated, then it was because the rise of the new science and its objective and rational approach to the study of nature took much of the wonder out of the observation of the physical world (Daston and Park, 1998). Central to the new, secular meaning of Enlightenment as a state of mind was the rejection of the marvellous. However, neither rationality nor science nor even secularization buried the wonders because they could and sometimes did entertain and terrify as well as induce awe. Nevertheless, deep inside, we still crave wonders waiting for the rare and extraordinary to surprise our souls.

\section{Acknowledgements}

We gratefully thank Heide Escher-Vetter (Bayerische Akademie der Wissenschaften, München) for discussing the melting of glaciers with us; and Martin Hagen and Winfried Beer (both DLR) for helping us to generate Figures 1 and 3 . 


\section{References}

Brinkmann WAT. 1974. Strong downslope winds at Boulder, Colorado. Mon. Wea. Rev. 102: 592-602.

Daston L, Park K. 1998. Wonders and the orden of nature. Zone Books: New York.

Escher-Vetter H. 2000. Modelling meltwater production with a distributed energy balance method and runoff using a linear reservoir approach - results from Vernagtferner, Oetztal Alps, for the ablation seasons 1992 to 1995. Zeitschr.f.

Gletscherkunde und Glazialgeologie, 36 119-150.

Hoinka KP. 1985. Observation of the airflow over the Alps during a foehn event.

Q. J. R. Meteorol. Soc. 111: 199-224.

Julian LT, Julian PR. 1969. Boulder's

winds. Weatherwise 22: 108-112.
Kerr AD. 1996. Bearing capacity of floating ice covers subjected to static, moving, and oscillatory loads. Appl. Mech. Rev. 49: 463-476.

Meichelbeck C. 1710. Leben, Leyden, Todt, Übersetzung und gnadenreiche Gutthätigkeit der großen heiligen Anastasia. München.

Pfister C. 1992. Monthly temperature and precipitation in central Europe from 17251979: Quantifying documentary evidence on weather and its effects, in Climate since A.D. 1500. Bradley RS, Jones PD (eds). Routledge: London; 118-142.

Schleich C. 1807. Loisach-Fluß, von der Tirolischen Gränze bis in die Isar unterhalb dem Markte Wolfratshausen, in: Hydrographische Karte. Von Riedl A, von Baiern S (eds). Lentnerische Buchhandlung: München.
Weber L. 1991. Zur Geschichte des Klosters Benediktbeuern, in Catalogue of the Exhibition in the Monastery Benediktbeuern Oktober 1991. Kirmaier J,

Treml M (eds). Veröffentlichung zur Bayerischen Geschichte und Kultur No. 21/91. München.

Correspondence to: Klaus P. Hoinka, Institut für Physik der Atmosphäre, DLR, Postfach 1116, D-82230 Weßling, Germany. Email:klaus.hoinka@dlr.de (c) Royal Meteorological Society, 2008 DOI: 10.1002/wea.251

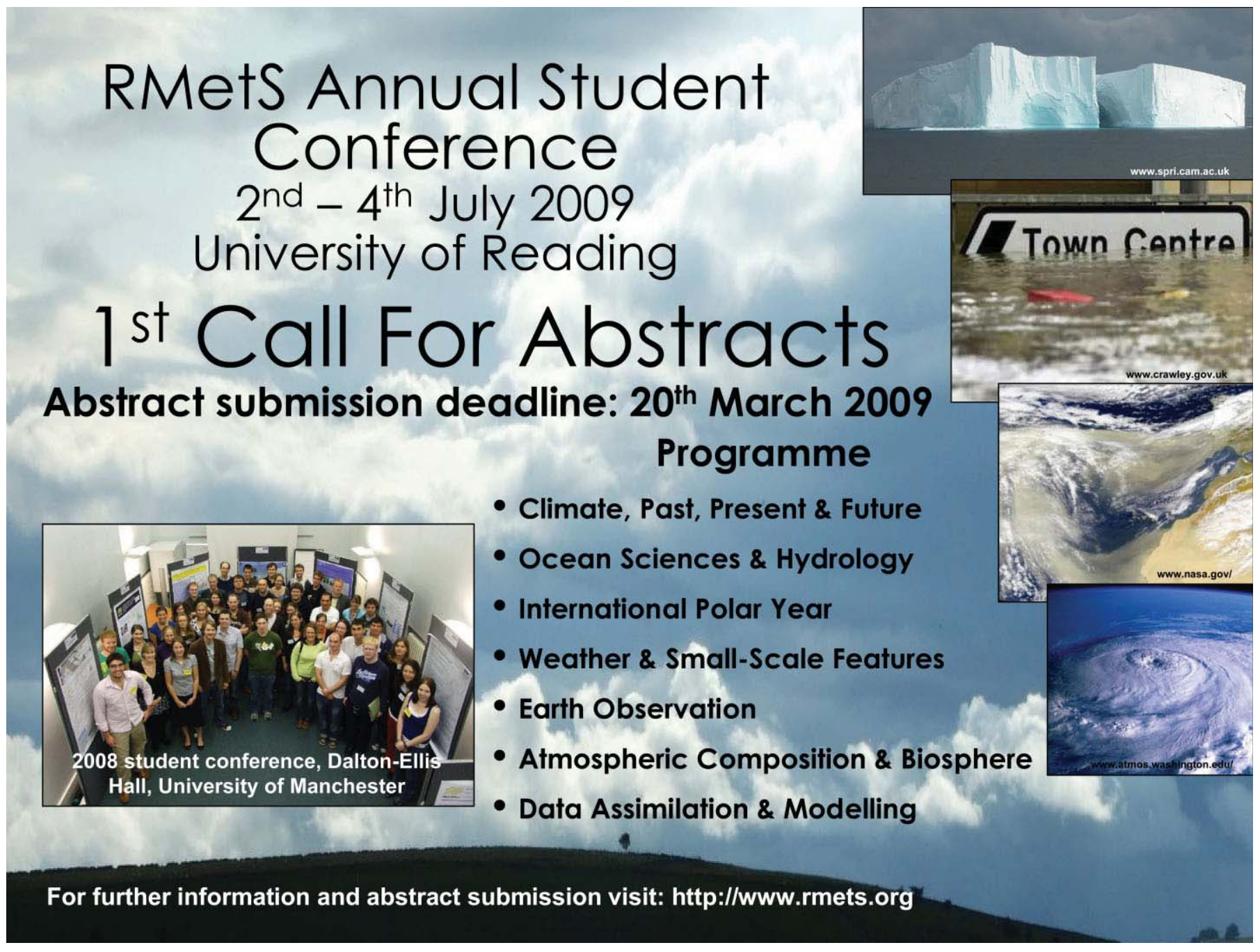

